\title{
Floriferous herbaceous and substrates for use on extensive green roofs ${ }^{(1)}$
}

\author{
PATRICK LUAN FERREIRA DOS SANTOS ${ }^{(2)^{*}}$, REGINA MARIA MONTEIRO DE CASTILHO(3))
}

\begin{abstract}
In general, extensive green roofs are defined as all cover covered with herbaceous vegetation and surface substratum, however, in Brazil there are few information regarding the materials for installation and maintenance of these systems, being essential the search for better species and substrates adapted to the tropical conditions. Thus, the objective was to evaluate the performance of floriferous herbaceous and substrates for use in extensive green roofs. The experiment was carried out in the field and in full sunlight, in black plastic containers ( $8.46 \mathrm{~L}$ and $15.5 \mathrm{~cm}$ high), elevated $90 \mathrm{~cm}$ from the ground, in a $3 \times 2$ factorial scheme. Being 3 herbaceous floriferous species (Torenia var. Kauai, Periwinkle var. Pacifica XP and Petunia var. Bacopa) and 2 substrates [S1-Charcoal + pine bark + peat + expanded vermiculite (1v:1v:1v:1v) and S2- Coconut fiber + carbonized rice husk + peat + expanded vermiculite (1v:1v:1v:1v)], with 3 replicates per treatment. It was evaluated in the substrates: $\mathrm{pH}$, electrical conductivity, macro and microporosity, total porosity, density and water retention capacity. For the development of the species, 60 days after the experiment installation, were evaluated, chlorophyll content of leaves, number of flowers and vegetation surface temperature. It was observed that the substrate S2 presented the best results in the physico-chemical analyzes, and this possibly came to reflect on the performance of the species, and that Torenia when cultivated in this substrate had the highest chlorophyll content (42.67 SPAD). The number of flowers was statistically the same for Torenia and Periwinkle in both substrates, while the three floriferous herbaceous plants showed a decrease in surface temperature. Thus, it is recommended for use on extensive green roofs the substrate composed of coconut fiber + carbonized rice husk + peat + expanded vermiculite (1v:1v:1v:1v), and the floriferous herbaceous Torenia var. Kauai.
\end{abstract}

Keywords: Torenia fournieri. Catharanthus roseus. Petunia x hybrid. Physical-chemical properties.

\section{RESUMO}

Herbáceas floríferas e substratos para uso em telhados verdes extensivos

De maneira geral, os telhados verdes extensivos são definidos como toda cobertura revestida de vegetação herbácea e substrato superficial, entretanto, no Brasil são poucas as informações referentes aos materiais para instalação e manutenção desses sistemas, sendo essencial a busca de melhores espécies e substratos adaptados as condições tropicais. Assim, objetivou-se avaliar o desempenho de herbáceas floríferas e substratos para uso em telhados verdes extensivos. O experimento foi realizado em campo e a pleno sol, em recipientes de plástico preto (8,46 L e 15,5 cm de altura), elevados a $90 \mathrm{~cm}$ do chão, em um esquema fatorial 3x2, sendo 3 espécies floríferas herbáceas (Torênia var. Kauai, Vinca var. Pacifica XP e Petúnia var. Bacopa) e 2 substratos [S1-Carvão vegetal + casca de pinus + turfa + vermiculita expandida (1v:1v:1v:1v) e S2- Fibra de coco + casca de arroz carbonizado + turfa + vermiculita expandida (1v:1v:1v:1v)], com 3 repetições por tratamento. Avaliou-se nos substratos: $\mathrm{pH}$, condutividade elétrica, macro e microporosidade, porosidade total, densidade e capacidade de retenção de água. Para o desempenho das espécies, após 60 dias da instalação do experimento, foram avaliados: teor de clorofila das folhas, número de flores e temperatura superficial da vegetação. Observou-se que o substrato S2, apresentou os melhores resultados nas análises físico-químicas, e isso possivelmente veio a refletir no desempenho das espécies, sendo que Torênia quando cultivada nesse substrato, apresentou o maior teor de clorofila (42,67 SPAD). O número de flores foi estatisticamente igual para Torênia e Vinca em ambos substratos, já as três herbáceas floríferas apresentaram diminuição da temperatura superficial. Dessa forma, recomenda-se para uso em telhados verdes extensivos o substrato composto de Fibra de coco + casca de arroz carbonizado + turfa + vermiculita expandida (1v:1v:1v:1v), e a herbácea florífera Torênia var. Kauai.

Palavras-chave: Torenia fournieri, Catharanthus roseus, Petunia x hybrida, propriedades físico-química.

\section{INTRODUCTION}

Green roofs, also known as ecological or living, can be defined, in general, as vegetation and substrate surfaces (VIJAYARAGHAVAN, 2016). Some are classified as extensive, because the growth substrate is more super- ficial, the plants are small in size and their maintenance cost relatively small (COMA et al., 2016). Depending on the technology used, and the geographical location, green roofs may comprise several components, including vegetation, substrate, filter cloth, drainage material, root barrier and insulation (VIJAYARAGHAVAN, 2016). These sys-

\footnotetext{
DOI: http://dx.doi.org/10.14295/oh.v24i3.1251

${ }^{(1)}$ Received in 02/07/2018 and accepted in 25/09/2018

(2)Universidade Estadual Paulista (UNESP), Faculdade de Ciências Agronômicas (FCA), Botucatu-SP, Brazil. "Corresponding author: patricklfsantos@ gmail.com

${ }^{(3)}$ Universidade Estadual Paulista (UNESP), Faculdade de Engenharia de Ilha Solteira (FEIS), Ilha Solteira-SP, Brazil.

Licensed by CC BY 4.0
} 
tems already account for about $20 \%$ of large metropolises in developed countries (RAJI et al., 2015), and are able to provide various benefits to urban areas in terms of aesthetic and environmental aspects (COMA et al., 2016).

Although innovators and technological, in Brazil there is little information and recommendations regarding the installation and maintenance of green roofs (Noya et al., 2017). This cause that professionals do not have adequate guidance and limits consumer protection (CONSELHO BRASILEIRO DE CONSTRUÇÂO SUSTENTÁVEL, 2014). In this way, investigations of the best components for use on green roofs, such as substrates and plant species, are essential to improve the sources of information.

According to Nagase et al. (2017) the most common vegetation used in the construction of these systems, are plants of the genus Sedum spp., because they can adapt to different environments. However, floriferous species must also be taken into account, since due to their exuberant flowers, they improve the aesthetics, increase the diversity of colors and forms (NAGASE et al., 2017) and attract pollinators that help in the dispersion of species (COLLA et al., 2009; ONDOÑO et al., 2015). Van Mechelen et al. (2014) say that in these projects, consideration should be given to the joining of annual and perennial species to improve the performance of the system.

Though, for extensive green roofs, the use of herbaceous floriferous is essential, due to the low root density they produce and their small size (MONTEIRO et al., 2017), which causes a decrease in the total structural load. Moreover, herbaceous plants that require little maintenance, water and that present high resistance to the adverse conditions, can be excellent options (MONTEIRO et al., 2017). Some authors have investigated these species for use in these systems (BENVENUTI, 2014; VAN MECHELEN et al., 2015, ONDOÑO et al., 2015), yet, they are plants of mainly Mediterranean climates, and the researches is recent (CASALINI et al., 2017), being necessary the search for plants adapted to the tropical conditions, due to the lack of works found in the literature.

Moreover, it is essential to know the best substrates for the development of these species, since according to Noya et al. (2017), the recommendations are based on international research, and most of the substrates are not available in Brazil. Thus, studies such as Willes and Reichardt et al. (2014), Santos et al. (2016b) and Noya et al. (2017) has sought solutions to fill this scarcity of information and adapt it to Brazilian conditions.

According to Kämpf and Fermino (2000) the ideal substrate is the one that offers greater porosity, because in addition to making better water filtration, it facilitates root growth, since it becomes the medium in which the roots develop, where for use in green roofs, should be a light and easily obtainable material (NOYA et al., 2017). Therefore, it is necessary to use mixtures of components, which must present physical and chemical properties necessary for the proper establishment and development of the species (SANTOS and CASTILHO, 2018).
Thus, the objective of this work was to evaluate the performance of floriferous herbaceous species and substrates for their potential use in extensive green roofs.

\section{MATERIAL AND METHODS}

The work was conducted on the field in full sun, in containers elevated $90 \mathrm{~cm}$ from the ground, supported by a metallic structure, each repetition being arranged randomly side by side, spaced around $10 \mathrm{~cm}$. The period of the experiment was April $1^{\text {th }}$ to June $4^{\text {th }}, 2016$; with average data of $23.7^{\circ} \mathrm{C}$ air temperature $\left(18.4^{\circ} \mathrm{C}\right.$ minimum and $30.5^{\circ} \mathrm{C}$ maximum) and $76.6 \%$ relative humidity $(51,5 \%$ minimum and 96,1\% maximum) (DADOS CLIMÁTICOS, 2016). The floriferous herbaceous species used were from the Company Ball Horticultural ${ }^{\circledR}$ of Holambra-SP, acquired in the shape of seedlings in trays (128 cells) of approximately $8 \mathrm{~cm}$ in size, being: Torenia var. Kauai (Torenia fournieri), Periwinkle var. Pacifica XP (Catharanthus roseus) and Petunia var. Bacopa (Petunia x hybrid, interspecific hybrid of $P$. axillaris BSP x $P$. violacea Lindl). For the substrates were used materials commonly recommended for Brazilian floriculture (KÄMPF et al., 2006). Two compositions were elaborated: Charcoal + pine bark + peat + expanded vermiculite $(1 \mathrm{v}: 1 \mathrm{v}: 1 \mathrm{v}: 1 \mathrm{v})$ and coconut fiber + carbonized rice husk + peat + expanded vermiculite $(1 \mathrm{v}: 1 \mathrm{v}: 1 \mathrm{v}: 1 \mathrm{v})$.

Thus, the experimental design was a completely randomized factorial scheme $(3 \times 2)$, with 3 floriferous herbaceous species and 2 substrates, totaling 6 treatments, with 3 replicates per treatment. For the installation of the experiment, each substrate was added in black plastic containers (47.5 x $17.5 \mathrm{~cm}$ nozzle, $41.5 \times 11.3 \mathrm{~cm}$ deep, height equal to $15.5 \mathrm{~cm}$, volume equal to 8.46 liters), with holes for drainage in the lower part, and later, 6 seedlings per container of each floriferous species were implanted.

These containers simulated the conditions of an extensive green roof (with limited length, height and volume), raised to $90 \mathrm{~cm}$ from the ground, and the bottom part of the containers functioning as a root barrier. As they were not in real condition on top of a building, it was not necessary to apply the waterproofing layer to prevent water infiltration, and the drainage system was based on gravity, with the holes in the bottom for water drainage. Irrigation management was carried out manually daily, and the containers received water until saturation, that is, until they were filled in order to ensure that the water factor did not interfere with the results of the experiment. Weed management was performed manually whenever necessary.

For analysis of the substrates, samples were taken on the day of installation of the experiment (April 1, 2016) being they were deformed. Were evaluated: $\mathrm{pH}$ (through of $\mathrm{pH}$ meter $\mathrm{pHTestr2}$ ) and Electrical Conductivity (EC), with the aid of the conductivity meter TDSTestr4, where a dilution of 1:5 of substrate and distilled water was used, according to the methodology described by Kämpf (2005). Furthermore, physical analyzes were performed according to the methodology cited by Zorzeto et al. (2014), evaluating the density and water retention capacity of substrate, 
and for the determination of macro, micro and total porosity, was used the method of Volumetric Ring in the Voltage Table, described by Pagliarini et al. (2012).

After approximately 60 days of the installation of the experiment (June $4^{\text {th }}, 2016$ ), was evaluated the performance of the herbaceous species in each substrate, for which was determined the chlorophyll content of the leaves with the support of the manual chlorophyllometer in SPAD readings. In addition, counted the total number of flowers per treatment, being the results expressed in $n^{\circ}$ flowers $m-2$. The surface temperature of the vegetation cover was evaluated on the leaf surface by means of a digital infrared laser thermometer, where the determination was carried out at approximately 12:00 a.m., as it is one of the hottest hours of the day. On the day of the evaluation, average temperature data of $22.8^{\circ} \mathrm{C}$ were recorded, with a maximum of $30.5^{\circ} \mathrm{C}$ and a minimum of $17.7^{\circ} \mathrm{C}$ (DADOS CLIMÁTICOS, 2016), and at the time of evaluation the thermometer indicated $30.1^{\circ} \mathrm{C}$ air temperature.
The results were submitted to analysis of variance (ANOVA) and Tukey test at the 5\% probability level for comparison of average, using the SISVAR statistical program (FERREIRA, 2014).

\section{RESULTS AND DISCUSSION}

It is observed that for the $\mathrm{pH}$ (Table 1), the best result was obtained by S2 (6.2) and there was a statistical difference between the treatments. According to Faquin (2005), $\mathrm{pH}$ has an indirect effect on nutrient absorption, being range of 6.0-6.5 more favorable for plant growth, since in this range the availability of some nutrients is maximum and not limiting to others, in this way, it is inferred that the substrate $\mathrm{S} 2$ will provide a better development of the species, which S1. However, Kämpf (2005) recommends a range of 5.2 to $5.5 \mathrm{pH}$ for cultivation of ornamental species, $\mathrm{S} 1$ being within the aforementioned.

Table 1. Average values of pH, Electric conductivity (EC), Macroporosity (Ma), Microporosity (Mi), Total Porosity (TP), Density (De) and Water Retention Capacity (WRC) in different substrates.

\begin{tabular}{|c|c|c|c|c|c|c|c|}
\hline \multirow{2}{*}{ Substrate } & $\mathbf{p H}$ & EC & Ma & Mi & TP & \multirow{2}{*}{$\begin{array}{c}\text { De } \\
\left(\mathrm{g} \mathrm{cm}^{-3}\right)\end{array}$} & \multirow{2}{*}{$\begin{array}{c}\text { WRC } \\
(\%)\end{array}$} \\
\hline & $\mathrm{H}_{2} \mathrm{O}$ & dS $\mathbf{m}^{-1}$ & \multicolumn{3}{|c|}{ - } & & \\
\hline $\mathrm{S} 1$ & $5.5 b$ & $0.42 b$ & $31.83 \mathrm{a}$ & $36.17 \mathrm{~b}$ & $68.00 \mathrm{~b}$ & $0.35 \mathrm{a}$ & $65.00 \mathrm{~b}$ \\
\hline $\mathrm{S} 2$ & $6.2 \mathrm{a}$ & $0.63 \mathrm{a}$ & $33.20 \mathrm{a}$ & $42.81 \mathrm{a}$ & $76.01 \mathrm{a}$ & $0.33 \mathrm{a}$ & $72.67 \mathrm{a}$ \\
\hline C.V.C $(5 \%)$ & 0.5 & 0.19 & 4.43 & 3.56 & 5.13 & 0.05 & 2.93 \\
\hline CV (\%) & 4.01 & 16.29 & 6.01 & 3.97 & 3.14 & 5.88 & 1.88 \\
\hline F & $13.36^{*}$ & $8.82^{*}$ & $0.74^{\text {ns }}$ & $26.98 * *$ & $18.83^{*}$ & $1.50^{\mathrm{ns}}$ & $52.90 * *$ \\
\hline
\end{tabular}

Average followed by the same lowercase letter in the column do not differ at the $5 \%$ level of significance by the Tukey test. ns- not significant; * significant at $5 \%$ by the F test; ** - significant at $1 \%$ by the F test. C.V.C. - Critical Value for Comparison. CV - Coefficient of Variation. S1-Charcoal + pine bark + peat + expanded vermiculite $(1 \mathrm{v}: 1 \mathrm{v}: 1 \mathrm{v}: 1 \mathrm{v})$ and S2- Coconut fiber + carbonized rice husk + peat + expanded vermiculite $(1 \mathrm{v}: 1 \mathrm{v}: 1 \mathrm{v}: 1 \mathrm{v})$.

The value obtained by S2 is because it is composed of carbonized rice husk. According to Noya et al. (2017) this material promotes a decrease in acidity, which possibly favored the result found, since it is in the range of $6.0-8.5$ recommended for green roofs in England (DESIGN, 2014), however it is out of the values of 6.87-8.21, observed by Chen et al. (2018) in study with substrates for this system in an experiment carried out in China, which are different from Brazilian conditions.

For the electrical conductivity (Table 1), there were statistical differences in the treatments, and again S2, presented higher result $\left(0.63 \mathrm{dS} \mathrm{m}^{-1}\right)$. However, according to Cavins et al. (2000) the values for the two substrates are considered normal, since they are in the ideal range established by the authors $\left(0.36\right.$ and $\left.0.65 \mathrm{dS} \mathrm{m}^{-1}\right)$. Already Noya et al. (2017) recommended for the development of herbaceous species on extensive green roofs, a substrate that presented EC of $1.94 \mathrm{dS} \mathrm{m}^{-1}$, a very high value when compared to the present study. However, Schafer et al. (2015) guarantee that when the values are greater than $0.65 \mathrm{dS} \mathrm{m}^{-1}$, the use of the substrate should be avoided in plant establishment, and in the present study, the results were below the mentioned. Ferraz et al. (2016) observed that in the EC of $0.65 \mathrm{dS} \mathrm{m}^{-1}$ the Petunia x hybrid and Torenia fournieri species had better development, and when the salinity level was increased, it was compromised.

For the macroporosity results, there was no significant statistical difference (Table 1). Santos et al. (2016b) evaluating different substrates for green roofs, found a range varying from 6.71 to $17.81 \%$, results very low to those of the present study. According to Reichert et al. (2009), the macropores are responsible for the aeration and contribution in the infiltration of water in the substrate, and thus the higher their value, the better these characteristics, however there was no statistical difference between the substrates of the present work, which shows that both have adequate macroporosity for species development.

For the microporosity values (Table 1), S2 presented a higher percentage $(42.81 \%)$, and it is in the range found by Santos et al. (2016b) in substrates for green roofs $(37.82$ to $45.23 \%$ ). However, the results of the two treatments are within those observed by Pagliarini et al. (2012) from 30.30 to $48.54 \%$ for seedling development. According to Lopes et al. (2008), optimal levels of micropores percentage of sub- 
strates for plant cultivation are in the range of 45 to $55 \%$, and in the present work, all values are below that mentioned.

When evaluating the Total Porosity data (Table 1), it was observed that S2 presented a higher percentage $(76.01 \%)$ than S1 (68\%), with a statistical difference between the two treatments. Kämpf and Fermino (2000) say that for the development of plants, the ideal substrate is one that offers greater porosity, because in addition to better filtering of water, it facilitates root growth, since it becomes the medium in which the roots develop, recommending values between 75 and $90 \%$. And in the present work, S2 is within the mentioned range, however Schafer et al. (2015), say that the optimal porosity for plant development is $85 \%$, and none of the treatments reached that value. Negase et al. (2017) obtained good results with green roof constructed with total porosity of $64 \%$, while Noya et al. (2017) recommended substrate of $94.39 \%$ for use in this system. Santos et al. (2016b) guarantee that for low maintenance green roofs, there is good development of plants with percentages ranging from 52.31 to $66.31 \%$, and in the present work, none of the treatments reached said values.

According to Santos and Castilho (2018) in general, the higher the total porosity of a substrate, the lower its density, and fact was observed in the present study (Table 1), however there was no difference between the results. The average height of extensive green roofs ranges from 6 to 20 $\mathrm{cm}$ for cultivation of herbaceous plants (DESGIN, 2014), and Kämpf (2005) recommends using substrates with a density of 0.25 to $0.40 \mathrm{~g} \mathrm{~cm}^{-3}$ for containers of up to $15 \mathrm{~cm}$ in height. The values of the present work within the mentioned (Table 1) and the height of the container of $15.5 \mathrm{~cm}$.

For extensive green roofs, density is one of the most important factors to be evaluated, since it directly influences the total system load as well as the development of the plants (DESIGIN, 2014). Noya et al. (2017) recommend a density substrate of $0.29 \mathrm{~g} \mathrm{~cm}^{-3}$ for an extensive green roof of $10 \mathrm{~cm}$ in height. However, Santos et al. (2016b) find values ranging from 0.92 to $1.50 \mathrm{~g} \mathrm{~cm}^{-3}$ and Chen et al. (2018) observed 0.94 to $1.09 \mathrm{~g} \mathrm{~cm}^{-3}$ in study with substrates for use in this system, being these values very high when compared to the present study.

Regarding the water retention capacity of the substrates, it was noted that there was a statistical difference between treatments (Table 1), where S2 presented the best result (72.67\%). This is because this substrate had high porosity and low density, and with this, it responded better in water storage. According to Schafer et al. (2015) water retention capacity assists in indicating the need for irrigation, and thus substrates with high values, can be used on green roofs without irrigation, in places where there is good rainfall distribution (NOYA et al., 2017). In addition, because S2 is composed of carbonized rice husk, the drainage of the roof will be favored, since this compound allows such fact (FERMINO and BELLÉ, 2008).

In this way, understanding the dynamics of solid-pore relationships is fundamental to success in the development of plants (LACERDA et al., 2006). Since cultivation on green roofs requires that the substrate maintain available water for the plant without to compromise the concentra- tion of oxygen in the medium (FERMINO, 2002), and thus it is expected that $\mathrm{S} 2$ presents better responses in the development of plant species than S1.

The chlorophyll content of the leaves showed that the substrate S2 [coconut fiber + carbonized rice husk + peat + expanded vermiculite $(1 \mathrm{v}: 1 \mathrm{v}: 1 \mathrm{v}: 1 \mathrm{v})]$ provided higher results for all species, being that Torenia var. Kauai found higher content (42.67 SPAD) (Table 2). Possibly because, this substrate presented the best results in chemical and physical analyzes (Table 1). The $\mathrm{pH}$ of 6.2 resulted in higher availability and nutrient uptake (FAQUIN, 2005) and EC $\left(0.63 \mathrm{dS} \mathrm{m}^{-1}\right)$ was close to $0.65 \mathrm{dS} \mathrm{m}^{-1}$, which allows a better development of Torenia (FERRAZ et al., 2016). Thus, these results reflected the chlorophyll content of the species. Another factor that may have contributed to the low results obtained by the species in S1 is that the substrate is composed of pine bark, which according to Noya et al. (2017) causes limitation of the absorption of water and nutrients, because it presents characteristics such as low aeration and low water retention capacity (SUGUINO et al., 2011). Therefore, there is a decrease in the development of the plants, which was evidenced in the present work.

In green roofs, it is essential plants with higher concentrations of chlorophyll due to the aesthetic aspect, since chlorophylls are responsible for the green tonality in the plants, and the greater the concentration in the foliar contents, the more intense is the coloration (GODOY et al., 2012). In addition, according to Taiz and Zeiger (2017), chlorophylls are molecules formed by complexes derived from porphyrin, having as the central atom the magnesium, bound to four others of nitrogen. Thus, there is a correlation between the chlorophyll index and the nutritional state of the plant (SANTOS and CASTILHO, 2015).

When comparing the number of flowers found (Table 2 ), it is observed that there is no statistical difference between the substrates, however, among species, it is observed a significant difference, with Torenia var. Kauai presenting best result when cultivated in S2 (473 $n^{\circ}$ Flores $\mathrm{m}^{-2}$ ) not differing from Periwinkle var. Pacifica XP (341 $\mathrm{n}^{\mathrm{o}}$ Flores $\mathrm{m}^{-2}$ ) in $\mathrm{S} 2$. As the species in question presented higher concentrations of leaf chlorophyll, physiologically, it has a great capacity of photosynthesizing carbohydrates (GUERTAL and FRANCK, 2012), and this possibly made its development faster and reflected in a greater number of flowers. However, because they belong to different species, the phenology of the herbaceous plants is distinct, and may differ in the flowering of each plant (MARTINI et al., 2010), as evidenced in the present work.

For the green roofs, is essential the greatest number of flowers, since in addition to improving the aesthetics of the place, it causes a greater attraction of pollinators and consequently greater dispersion of species (COLLA et al., 2009; ONDÕNO et al., 2015). According to Santos et al. (2016a) an ideal pollinator should visit flowers of different individuals of the same species, thus ensuring that the pollen transfer takes place between the co-specific plants, and the greater the number of flowers, the more chance there is of efficient pollination on green roofs. 
Table 2. Average values of chlorophyll content, number of flowers and surface temperature of each herbaceous species cultivated on substrates.

\begin{tabular}{|c|c|c|c|c|c|c|}
\hline \multirow{3}{*}{ Species } & \multicolumn{2}{|c|}{ chlorophyll } & \multicolumn{2}{|c|}{ Flowers } & \multicolumn{2}{|c|}{ Temperature } \\
\hline & \multicolumn{2}{|c|}{ SPAD } & \multicolumn{2}{|c|}{$\mathrm{n}^{\circ}$ Flowers $\mathrm{m}^{-2}$} & \multicolumn{2}{|c|}{${ }^{o} \mathrm{C}$} \\
\hline & S1 & $\mathrm{S} 2$ & S1 & S2 & $\mathrm{S} 1$ & $\mathrm{~S} 2$ \\
\hline Torenia var. Kauai & $33.33 \mathrm{aB}$ & $42.67 \mathrm{aA}$ & $405 \mathrm{aA}$ & $473 \mathrm{aA}$ & $27.01 \mathrm{aA}$ & $23.42 \mathrm{aB}$ \\
\hline Periwinkle var. Pacifica XP & $29.42 \mathrm{bB}$ & $33.12 \mathrm{bA}$ & $265 \mathrm{abA}$ & $341 \mathrm{abA}$ & $28.3 \mathrm{aA}$ & $24.00 \mathrm{aB}$ \\
\hline Petunia var. Bacopa & $29.67 \mathrm{bB}$ & $36.04 \mathrm{bA}$ & $148 \mathrm{bA}$ & $197 \mathrm{bA}$ & $28.17 \mathrm{aA}$ & $23.61 \mathrm{aB}$ \\
\hline C.V.C. line (5\%) & \multicolumn{2}{|c|}{2.75} & \multicolumn{2}{|c|}{192} & \multicolumn{2}{|c|}{2.10} \\
\hline C.V.C. column (5\%) & \multicolumn{2}{|c|}{3.37} & \multicolumn{2}{|c|}{235} & \multicolumn{2}{|c|}{2.57} \\
\hline $\mathrm{CV}(\%)$ & \multicolumn{2}{|c|}{4.55} & \multicolumn{2}{|c|}{35.37} & \multicolumn{2}{|c|}{4.56} \\
\hline F spec. $\mathrm{x}$ subst. & \multicolumn{2}{|c|}{$5.05^{*}$} & \multicolumn{2}{|c|}{$0.03^{\text {ns }}$} & \multicolumn{2}{|c|}{$0.36^{\text {ns }}$} \\
\hline
\end{tabular}

Average followed by the same lowercase letter in the column, and the same capital letter in the row do not differ at the $5 \%$ level of significance by the Tukey test. ns- not significant; * - significant at $5 \%$ by the F test; ** - significant at $1 \%$ by the F test. C.V.C. - Critical Value for Comparison. CV - Coefficient of Variation. S1-Charcoal + pine bark + peat + expanded vermiculite (1v:1v:1v:1v) and S2- Coconut fiber + carbonized rice husk + peat + expanded vermiculite $(1 \mathrm{v}: 1 \mathrm{v}: 1 \mathrm{v}: 1 \mathrm{v})$

However, one should take into account the preference of pollinating agents for the plants, some studies have shown that Petunia species present bees of the genus Hexanthaeda missionic faithful at the time of pollination (SANTOS et al., 2016a), which may be associated with physiological aspects of its flowers. According to Van Moerkercke et al. (2012), Petunia hybrid has been the target of many researchers in recent years for studies of the biosynthesis and regulation of floral aromas that exude. Also, there is research that the species may contain compounds, which act in the protection against UV rays, lignification, protection against pathogens and flower pigmentation (VOGT, 2010), characteristics that for green roofs are essential for species conservation. In the present study, the number of flowers evidenced by Petunia var. Bacopa, were the smallest, being statistically equal only to Periwinkle var. Pacifica XP, however, due to the adaptive characteristics of the species, infers that it can be a good choice for green roofs and to attract a lot of pollinators even in low number of flowers.

In the same way, if pollination occurs, consequently the production of seeds occurs, which comes to fall on the substrate and generate new individuals, without the need to purchase new seedlings. Thus, the green roof will act as a kind of "seed bank" for propagation and dispersion of plants (ONDOÑO et al., 2015). Like, Torenia var. Kauai presented a higher number of flowers, it is expected that the amount of seeds produced by the plant will be higher, since this species has a high frequency of pollinators, as evidenced by Dec and Mouga et al. (2014).

It is worth mentioning that Periwinkle var. Pacifica XP, presented intermediate numbers of flowers in the substrates (265 and 341 flowers $\mathrm{m}^{-2}$ in $\mathrm{S} 1$ and $\mathrm{S} 2$ respectively) (Table 2 ), however, this is a species that can also be indicated for extensive green roofs. According to Lorenzi (2015), it is adapted to different environments and grows very well in hot, dry and sunny conditions, and for green roofs, it is recommended to use herbaceous plants that require little maintenance and water and show high resistance to adverse conditions (MONTEIRO et al., 2017), being then, Periwinkle var. Pacifica XP a possible option.

The surface temperature of the vegetation cover showed statistically that the species when cultivated in substrate 2 showed the lowest values, being Torenia var. Kauai (23.42 $\left.{ }^{\circ} \mathrm{C}\right)$, Periwinkle var. Pacifica XP $\left(24.00^{\circ} \mathrm{C}\right)$ and Petunia var. Bacopa $\left(23.61{ }^{\circ} \mathrm{C}\right)$, which represents a reduction of 6.68 ${ }^{\circ} \mathrm{C}(22.20 \%), 6.10^{\circ} \mathrm{C}(20.27 \%)$ and $6.49{ }^{\circ} \mathrm{C}(21.56 \%)$, respectively, of the value shown by the thermometers at the time of the measurement $\left(30.1^{\circ} \mathrm{C}\right)$. Matheus et al. (2016) in a study with thermal performance of vegetation cover in buildings, observed a reduction of $9{ }^{\circ} \mathrm{C}$ in the hottest times of the day when they compared the temperature of the ceramic tiles with the vegetation, value this close to the decrease achieved in the present study.

There was no statistical difference between species, however, when comparing the two substrates, it was observed that S2 presented lower results than S1 (Table 2). This is due to the physical attributes of each substrate (Table 1). Like S2 presented lower density $\left(0.33 \mathrm{~g} \mathrm{~cm}^{-3}\right)$, higher total porosity $(76.01 \%)$ and higher water retention capacity $(72.67 \%)$, the substrate tends to stay moist for longer, causing the water to help decrease the temperature (BRADY and WEIL, 2012) and thus, together with the vegetation, lower values were observed in S2. Santos et al. (2016b) observed that substrates with lower porosity and higher densities caused an increase in green roof temperature, which was evidenced in the present study in S1.

This reduction in temperature is essential in large cities, since they minimize "heat island" phenomena, caused by the excessive amount of buildings that waterproof the previously permeable areas, increasing the local temperature (TEIXEIRA and AMORIM, 2017). Thus, as Torenia var. Kauai cultivated in substrate 2 showed a reduction of $22.20 \%$, it is inferred that the species and the substrate, when on green roofs, present ideas characteristics to diminish the mentioned effect. However, the decrease achieved 
is below the $40 \%$ that can arrive on hot summer days, cited by Dreher et al. (2016).

It should be noted that the values found are of surface temperature of the vegetation, where for the internal temperature of the place with which the green roof will be installed, the results tend to decrease even more. According to Perussi and Vecchia (2017), green roofs block the incident solar radiation, allowing the upper surface not to reach values above the daily maximum, which causes a decrease of the internal temperature of the building. Thus, the roof helps to keep the site more comfortable, which can result in lower energy bills due to the possible reduction of air conditioning (SANTOS et al., 2016b). In the present study, it is expected that substrate 2 be more efficient in the reduction of the internal temperature than the other treatments, given the reduction value of the surface temperature.

Second, Santos et al. (2016b) as in extensive green roofs the substrate thickness is smaller, they are more dependent on plant cover to minimize their heating due to shading caused by plants. Thus, once exposed, the substrate acts as a thermal energy accumulator, rapidly transferring this energy to the medium (PERUSSI and VECCHIA, 2017), resulting in higher surface temperatures. This fact possibly occurred in the cultivation of species on substrate 1 .

\section{CONCLUSIONS}

It is recommended for use on extensive green roofs, the substrate composed of coconut fiber + carbonized rice husk + peat + expanded vermiculite $(1 \mathrm{v}: 1 \mathrm{v}: 1 \mathrm{v}: 1 \mathrm{v})$.

The three floriferous herbaceous can be used to decrease the surface temperature, however, Torenia var. Kauai presented the best values of chlorophyll and number of flowers, being this species is recommended for use in this system.

\section{ACKNOWLEDGMENTS}

The authors are thankful to company Ball Horticultur$\mathrm{al}^{\circledR}$ of Holambra-SP for the donation of the seedlings of the floriferous herbaceous species for the execution of the experiment

\section{AUTHORS CONTRIBUTIONS}

P.L.F.S D0000-0002-1956-1030: Idea of the experiment, field analysis, data collection and analysis, interpretation, preparation and writing of the article, critical review R.M.M.C. D0000-0003-3421-7235: Adviser of work, analysis and interpretation of data, critical review of the article, approval of the final version of the article.

\section{REFERENCES}

BENVENUTI, S. Wildflower green roofs for urban landscaping, ecological sustainability and biodiversity. Landscape and Urban Planning, v.124, p.151-161, 2014. DOI: https://doi.org/10.1016/j.landurbplan.2014.01.004
BRADY, N.C.; WEIL, R.R. Elementos da Natureza e Propriedades dos Solos. $3^{\circ}$ ed. Porto Alegre: Editora Bookman, 2012. 716p.

CASALINI, R.; BARTOLI, F.; CANEVA, G. Investigation of seed germination of twelve Mediterranean wildflowers for evaluating their potential use on extensive green roofs. Acta Horticulturae, v.1189, p.263-266, 2017. DOI: https://doi.org/10.17660/ActaHortic.2017.1189.50

CAVINS, T.J.; WHIPKER, B.E.; FONTENO, W.C.; HARDEN, B.; MCCALL, I.; GIBSON, J.L. Monitoring and managing $\mathrm{pH}$ and $\mathrm{EC}$ using the PourThru Extraction Method. Horticulture Information Leaflet 590, New 7/2000. Raleigh: North Caroline State University, 2000. $17 \mathrm{p}$.

CHEN, H.; MA, J.; WEI, J.; GONG, X.; YU, X.; XICHEN, Y.; GUO H.; ZHAO, Y. Biochar increases plant growth and alters microbial communities via regulating the moisture and temperature of green roof substrates. Science of The Total Environment, v.635, p.333-342, 2018. DOI: https:// doi.org/10.1016/j.scitotenv.2018.04.127

COLLA, S.R.; WILLIS, E.; PACKER, L. Can green roofs provide habitat for urban bees (Hymenoptera: Apidae)?. Cities and the Environment (CATE), v.2, n.1, 2009. DOI: http://dx.doi.org/10.15365/cate.2142009

COMA, J.; PÉREZ, G.; SOLÉ, C.; CASTELL, A.; CABEZA, L.F. Thermal assessment of extensive green roofs as passive tool for energy savings in buildings. Renewable Energy, v.85, p.1106-1115, 2016. DOI: https://doi. org/10.1016/j.renene.2015.07.074

CONSELHO BRASILEIRO DE CONSTRUÇÂO SUSTENTÁVEL. Posicionamento sobre o PL $\mathbf{n}^{\circ}$ 1.703/11: Telhados Verdes no Brasil. Jun. 2014. 4p. Disponível em:< http://www.cbcs.org.br/_5dotSystem/userFiles/posicionamentos/CBCS_Posicionamento_Telhados-Verdes. pdf $>$. Acessed in: December $18^{\text {th }} 2017$.

DADOS CLIMÁTICOS - ILHA SOLTEIRA/SP. Canal CLIMA da UNESP Ilha Solteira - Área de Hidráulica e Irrigação. Available in: <http://clima.feis.unesp.br/ recebe_formulario.php>. Accessed in: August 20 2016.

DEC, E.; MOUGA, D.M.D.S. Diversidade de abelhas (Hymenoptera: Apidae) em área de mata atlântica em Joinville, Santa Catarina. Acta Biológica Catarinense, v.1, n.2, 2014. DOI: http://dx.doi.org/10.21726/abc.v1i2.91

DESIGN, J.W. The GRO Green Roof Code: Green Roof Code of Best Practice for the UK. $2^{\circ}$ ed. Sheffield: Groundwork Sheffield, 2014. 36p. 
DREHER, A.R.; JACOSKI, C.A.; MEDEIROS, R. Conceitos de bioclimatologia e sustentabilidade aplicados a fase de projeto em habitações de interesse social. Revista da Universidade Vale do Rio Verde, v.14, n.1, p.145-159, 2016. DOI: http://dx.doi.org/10.5892/ruvrd.v14i1.2448

\section{FAQUIN, V. Nutrição Mineral de Plantas. Lavras: UFLA/} FAEPE, 2005. 186 p.

FERMINO, F.H. O uso da análise física na avaliação da qualidade de componentes em substratos. In: FURLANI, A.M.C.; BATAGLIA, O.C.; ABREU, M.F.; ABREU, C.A.; FURLANI, P.R., QUAGGIO, J.A.; MINAMI, K. Caracterização, manejo e qualidade de substratos para a produção de plantas. Campinas: Instituto Agronômico, 2002. p. 29-37.

FERMINO, M.H.; BELLÉ, S. Substrato para plantas. In: PETRY, C. Plantas ornamentais: aspectos para a produção. Passo Fundo: Editora UPF, 2008. p. 46-58.

FERRAZ, M.V.; FRANCO, C.F.; BATISTA, G.S.; PIVETTA, K.L.P. Salinity on the germination of seed and index of germination speed of three ornamental species. Ornamental Horticulture, v.22, n.2, 2016, p.196-201. DOI: https://doi.org/10.14295/oh.v22i2.919

FERREIRA, D. F. Sisvar: a Guide for its Bootstrap procedures in multiple comparisons. Ciência e Agrotecnologia, v.38, n.2, p.109-112, 2014. DOI: http:// dx.doi.org/10.1590/S1413-70542014000200001

GODOY, L.J.G. de; VILLAS BÔAS, R.L.; BACKES, C.; SANTOS, A. J. M. Nutrição, Adubação e Calagem para produção de gramas. 1 Ed. Botucatu: Editora FEPAF, 2012. 146p.

GUERTAL, E.; FRANK, K. Adubação nitrogenada, fosfatada e potássica para gramas. In: BACKES, C.; GODOY, L.J.G.; MATEUS, C.M.D.; SANTOS, A.J.M.; VILLAS BÔAS, R.L.; OLIVEIRA, M.R. Tópicos atuais em gramados III. Botucatu: Editora FEPAF, 2012. p.3963.

KÄMPF, A.N. Produção comercial de plantas ornamentais. 2 ed. Guaíba: Agrolivros, 2005. 256p.

KÄMPF, A.N.; FERMINO, M.H. Substratos para plantas: a base da produção vegetal em recipientes. Porto Alegre: Gênesis, 2000. 312p.

KÄMPF, A.N.; TAKENE, R. J.; SIQUEIRA, P. T. V. D. Floricultura: técnicas de preparo de substratos. Brasília: LK Editora e Comunicação, 2006. 132p.
LACERDA, M.R.B.; PASSOS, M.A.A.; RODRIGUES, J.J.V.; BARRETO, L.P. Características físicas e químicas de substratos à base de pó de coco e resíduo de sisal para produção de mudas de sabiá (Mimosa caesalpiniaefolia Benth). Revista Árvore, v.30, n.2, p.163-170, 2006. DOI: http://dx.doi.org/10.1590/S0100-67622006000200002

LOPES, J.L.W.; GUERRINO, I.A.; SAAD, J.C.C.; SILVA, M.R. Atributos químicos e físicos de dois substratos para produção de mudas de eucalipto. Cerne, v.14, n.4, p.358$367,2008$.

LORENZI, H. Plantas para jardim no Brasil: herbáceas, arbustivas e trepadeiras. 2 ed. Nova Odessa: Instituto Plantarum, 2015. 1120p.

MARTINI, A.; BIONDI, D.; BATISTA, A.C.; NATAL, C.M. Fenologia de espécies nativas com potencial paisagístico. Semina: Ciências Agrárias, v.31, n.1, p.75-84, 2010. DOI: http://dx.doi.org/10.5433/16790359.2010v31n 1 p 75

MATHEUS, C.; CAETANO, F.D.N.; MORELLI, D.D.O.; LABAKI, L.C. Desempenho térmico de envoltórias vegetadas em edificações no sudeste brasileiro. Ambiente construído. v.16, n.1, p.71-81, 2016. DOI: http://dx.doi. org/10.1590/s1678-86212016000100061

MONTEIRO, C.M.; CALHEIROS, C.S.C.; MARTINS, J.P.; COSTA, F.M.; PALHA, P.; FREITAS, S.; RAMOS, N.M.M.; CASTRO, P.M.L. Substrate influence on aromatic plant growth in extensive green roofs in a Mediterranean climate. Urban Ecosystems, v.20, n.6, p.1347-1357, 2017. DOI: https://doi.org/10.1007/s11252-017-0687-9

NAGASE, A.; DUNNETT, N.; CHOI, M.S. Investigation of plant growth and flower performance on a semi-extensive green roof. Urban Forestry \& Urban Greening, v.23, p.6173, 2017. DOI: https://doi.org/10.1016/j.ufug.2017.01.013

NOYA, M.G.; CUQUEL, F.L.; SCHAFER, G.; ARMINDO, R.A. Substrates for cultivating herbaceous perennial plants in extensive green roofs. Ecological Engineering, v.102, p.662-669, 2017. DOI: https://doi.org/10.1016/j. ecoleng.2017.02.042

ONDOÑO, S.; MARTÍNEZ-SÁNCHEZ, J.J.; MORENO, J.L. Evaluating the growth of several Mediterranean endemic species in artificial substrates: Are these species suitable for their future use in green roofs? Ecological Engineering, v.81, p.405-417, 2015. DOI: https://doi. org/10.1016/j.ecoleng.2015.04.079 
PAGLIARINI, M.K.; CASTILHO, R.M.M.; ALVES, M.C. Caracterização físico-química de misturas de componentes de substrato com resíduo de celulose para fins de produção de mudas. Revista Brasileira de Agroecologia, v.7, n.2, p.160-169, 2012.

PERUSSI, R.; VECCHIA, F.A.S. Análise do comportamento térmico de um sistema de cobertura verde utilizando plataformas de teste. Pesquisa em Arquitetura e Construção, v.7, n.4, p.225-236. DOI: https://doi. org/10.20396/parc.v7i4.8647932

RAJI, B.; TENPIERIK, M.J.; DOBBELSTEEN, A.V. The impact of greening systems on building energy performance: a literature review. Renewable and Sustainable Energy Reviews, v.45, p.610-623, 2015. DOI: https://doi.org/10.1016/j.rser.2015.02.011

REICHERT, J. M.; KAISER, D. R.; REINERT, D. J.; RIQUELME, U. F. B. Variação temporal de propriedades físicas do solo e crescimento radicular de feijoeiro em quatro sistemas de manejo. Pesquisa Agropecuária Brasileira, v.44, n.3, p.310-319, 2009. DOI: http://dx.doi. org/10.1590/S0100-204X2009000300013

SUGUINO, E.; MARTINS, A.N.; MINAMI, K.; NARITA, N.; PERDONÁ, M.J. Efeito da porosidade do substrato casca de pínus no desenvolvimento de mudas de grumixameira. Revista Brasileira de Fruticultura. v.33, p.643-648, 2011. DOI: http://dx.doi.org/10.1590/S010029452011000500089

SANTOS, I.A.; SILVA, C.I.; PINHEIRO, M.; KLEINERT, A.M.P. Quando um visitante floral é um polinizador? Rodriguésia, v.67, n.2, p.295-307, 2016a. DOI: http:// dx.doi.org/10.1590/2175-7860201667202

SANTOS, P.L.F.; CASTILHO, R.M.M. Relação entre teor de clorofila e nitrogênio foliar em grama esmeralda cultivada em substratos. Tecnologia \& Ciência Agropecuária, v.9, n.2, p.51-54, 2015 .

SANTOS, P.L.F.; BARCELOS, J.P.Q.; CASTILHO, R.M.M. Diferentes substratos no desenvolvimento de um gramado ornamental para uso em telhados verdes. Periódico Técnico e Científico Cidades Verdes, v.4, n.10, p.81-94, 2016b. DOI: http://dx.doi.org/10.17271/2317860 441020161393

SANTOS, P.L.F.; CASTILHO, R.M.M. Substrates in the development of a sports turfgrass "Tifton 419". Ornamental Horticulture, v.24, n.4, p.138-144, 2018. DOI: https://doi.org/10.14295/oh.v24i2.1155
SCHAFER, G.; SOUZA, P.V.D.; FIOR, C.S. Um panorama das propriedades físicas e químicas de substratos utilizados em horticultura no sul do Brasil. Ornamental Horticulture, v.21, n3, p. 299-306, 2015. DOI: https://doi. org/10.14295/oh.v21i3.735

TAIZ, L.; ZEIGER, E. Fisiologia e desenvolvimento vegetal. $6^{\circ}$ edição. Porto Alegre: Editora Artmed, 2017. $858 \mathrm{p}$.

TEIXEIRA, D.C.F.; AMORIM, M.C.C.T. Ilhas de calor: representações espaciais de cidades de pequeno porte por meio de modelagem. Geousp - Espaço e Tempo, v.21, n.1, p.239-256, 2017. DOI: http://dx.doi.org/10.11606/ issn.2179-0892.geousp.2017.113406

VAN MECHELEN, C.; DUTOIT, T.; HERMY, M. Mediterranean open habitat vegetation offers great potential for extensive green roof design. Landscape and Urban Planning, v.121, p.81-91, 2014. DOI: https://doi. org/10.1016/j.landurbplan.2013.09.010

VAN MECHELEN, C.; DUTOIT, T.; HERMY, M. Vegetation development on different extensive green roof types in a Mediterranean and temperate maritime climate. Ecological Engineering, v.82, p.571-582, 2015. DOI: https://doi.org/10.1016/j.ecoleng.2015.05.011

VAN MOERKERCKE, A.; GALVÁN-AMPUDIA, C.S.; VERDONK, J.C.; HARING, M.A.; SCHUURINK, R.C. Regulators of floral fragrance production and their target genes in petunia are not exclusively active in the epidermal cells of petals. Journal of Experimental Botany, v.63, n.8, p.3157-3171, 2012. DOI: https://doi.org/10.1093/jxb/ ers034

VIJAYARAGHAVAN, K. Green roofs: A critical review on the role of components, benefits, limitations and trends. Renewable and Sustainable Energy Reviews. v.57, p.740752, 2016. DOI: https://doi.org/10.1016/j.rser.2015.12.119

VOGT, T. Phenylpropanoid biosynthesis. Molecular Plant, v.3, n.1, p.2-10, 2010. DOI: https://doi.org/10.1093/ $\mathrm{mp} / \mathrm{ssp} 106$

WILLES, J.A.; REICHARDT, K. Tecnologias em telhados verdes extensivos: substratos comerciais regionais mais apropriados ao sistema. Revista Internacional de Ciências, v.4, n.2, p.02-13, 2014. DOI: https://doi. org/10.12957/ric.2014.11406

ZORZETO, T.Q.; DECHEN, S.C.F.; ABREU, M.F.; FERNANDES JUNIOR, F. Caracterização física de substratos para plantas. Bragantia, v.73, n3, 2014. DOI: http://dx.doi.org/10.1590/1678-4499.0086 